\title{
Aberrant Clonal Plasma Cell Population
}

National Cancer Institute

\section{Source}

National Cancer Institute. Aberrant Clonal Plasma Cell Population. NCI Thesaurus. Code C159854.

A population of plasma cells which display atypical morphological features, an abnormal immunophenotypic profile, and molecular genetic characteristics of clonality (monoclonality). 